\title{
New anesthetic programs for big elderly in day surgery
}

\author{
F Oliva*, G Dimarzio, M De Vizia, B Lettieri \\ From XXIII Annual Meeting of the Italian Society of Geriatric Surgery \\ Lecce, Italy. 2-4 December 2010
}

\section{Background}

Today the availability of new local anesthetics and the use of analgesics, allow the modulation of analgesia, maintaining a state of consciousness.

An answer to the needs of patients $>75$ years undergoing surgery is the technique Monitored Anesthesia Care (MAC), defined "the middle land" (ASA 2003 - S. Francisco) Figure 1.

\section{Materials and methods}

A study was conducted in double-blind, random, with 86 patients subjected to two different regimens of sedation with midazolam and propofol, pain with remifenta-

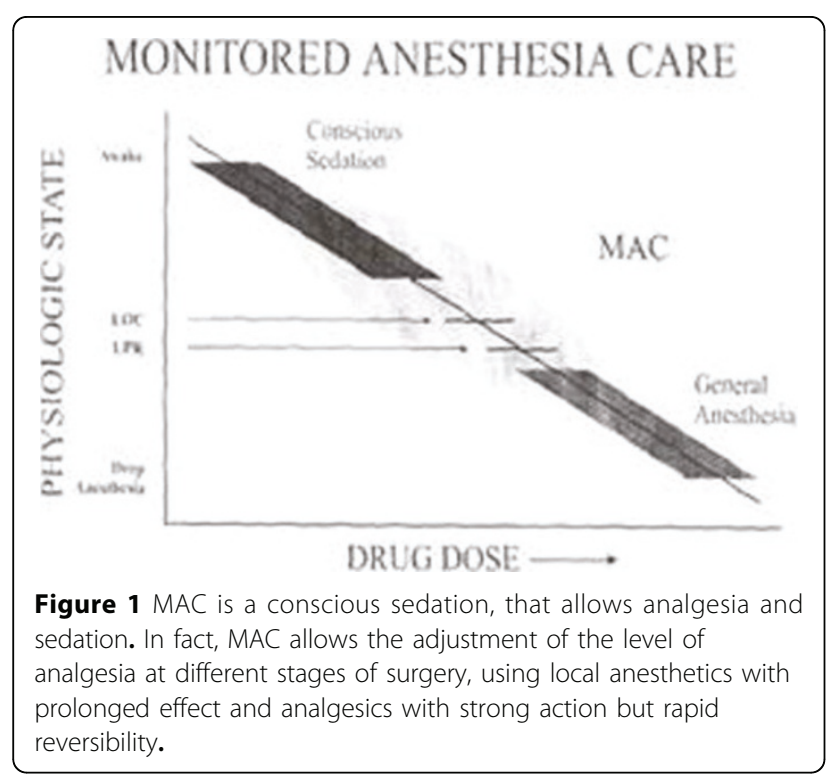

Department of Anaesthesia, Surgical and Emergency Science, Second University of Naples, Italy

Full list of author information is available at the end of the article nil. Inclusion criteria: age $>70$ years, body weight $69 \pm 6$ $\mathrm{kg}$, informed consent MAC, ASA II-III stabilized cardiovascular and respiratory conditions ( $\mathrm{pO} 2 \leq 70$ and $\mathrm{pCO} 2$ $<45 \mathrm{mmHg}$ ). Exclusion criteria: risk of bleeding, ASA III in acute, severe neurological disorders, severe hepatic dysfunction. During surgery, the monitoring of the level of sedation and mental status was performed comparing three methods of assessment: the clinical evaluation of drug effects on the CNS (Observer Assessment of Alertness/Sedation scale OAA/S), MAC has a sedation level of 3-4, the assessment of sedation according to Ramsay scale, and instrumental evaluation (Bispectral Index $\mathrm{BIS})$. The clinical procedure was: $\mathrm{O} 2$ inhalation when the area was infiltrated with local anesthetic or BNP, when patients had pain a continuous infusion of remifentanil was activated: 0.025 to $0.05 \mathrm{mcgr} / \mathrm{kg} / \mathrm{m}$. Patients were dichotomized randomly into two groups with different sedation: group P (45 patients), starter bolus of $0.5 \mathrm{mg} / \mathrm{kg}$ propofol and continuous infusion of propofol $1-2 \mathrm{mg} / \mathrm{kg} / \mathrm{h}$; group $\mathrm{M}$ (41 patients), starter bolus of 0.03 to $0.05 \mathrm{mg} / \mathrm{kg}$ midazolam and then infusion of $1-2$ $\mu \mathrm{gr} / \mathrm{kg} / \mathrm{h}$. Tables 1 and 2.

\section{Results}

The scale of Ramsay sedation and OAA/S showed similar results, BIS values $>70$ represented a significant predictor in the study of a more rapid recovery of state of consciousness, which has favored fast tracking. One fact that emerged from the study: the 3 scores of sedation

Table 1

\begin{tabular}{lllll}
\hline & T 10 min & T 20 min & T 30 min & T 40 min \\
\hline BIS & $72(28-95)$ & $66(20-98)$ & $70(15-98)$ & 74 (30-98) \\
OAA/S & $4(1-5)$ & $3-4(1-5)$ & $3-4(1-5)$ & $4(1-5)$ \\
Ramsay & $3-4(1-6)$ & $4(1-6)$ & $3-4(1-6)$ & $3-4(1-6)$ \\
\hline
\end{tabular}

media dei valori strumentali e clinici del gruppo $\mathrm{P}$ 
Table 2

\begin{tabular}{lllll}
\hline & T $10 \mathrm{~min}$ & T $20 \mathrm{~min}$ & T 30 min & T 40 min \\
\hline BIS & $64(18-96)$ & $58(15-93)$ & $62(16-94)$ & $66(20-98)$ \\
OAA/S & $4(1-5)$ & $3-4(1-5)$ & $3-4(1-5)$ & $3-4(1-5)$ \\
Ramsay & $3-4(1-6)$ & $4(1-6)$ & $3-4(1-6)$ & $3-4(1-6)$ \\
\hline
\end{tabular}

media dei valori strumentali e clinici del gruppo $\mathrm{M}$

Table 3

\begin{tabular}{llll}
\hline & Midadolam & Propofol & Remifentanil \\
\hline onset of sedation & fast & moderate & fast \\
drug effects recovery & fast & slow & fast \\
pain at injection & yes & no & no \\
intra-postoperative pain & moderate & moderate & minimal \\
hemodynamic depression & moderate & minimal & minimal \\
respiratory variations & slight desaturation & minimal & minimal \\
& $(<30 \%)$ & & \\
ponv & minimal & minimal & minimal \\
\hline
\end{tabular}

are significantly correlated $(\mathrm{P}<0.001)$, but this correlation is lost in the M group when the values of BIS $\leq 70$ in respiratory parameters is compromised greater than in group $\mathrm{P}(\mathrm{P}=0.001)$ Table 3.

\section{Conclusions}

The observation is consistent with results of White Anesth.Analgesia '99, regarding the dose-effect curve of midazolam on the spectrum of activity of the CNS, three times higher than propofol. This leads to being more cautious in the use of midazolam in the MAC procedures.

Published: 24 August 2011

\section{References}

1. Chen L, Tang J, White PF, et al: The effect of location of transcutaneous electrical nerve stimulation on post-operative opioid analgesic requirement: acupoint versus nonacupoint stimulation. Anesth Analg 1998, 87:1129-34.

2. Gajraj RJ, Doi M, Mantzaridis H, Kenny GN: Analysis of the EEG bispectrum, auditory evoked potentials and the EEG power spectrum during repeated transitions from consciousness to unconsciousness. $\mathrm{Br} J$ Anaesth 1998, 80(1):46-52.

3. Murdoch JA, Hyde RA, Kenny GN: Target-controlled remifentanil in combination with propofol for spontaneously breathing day-case patients. Anaesthesia 1999, 54(11):1028-31.

4. Bonhomme V, Plourde G, Meuret P: Auditory steady-state response and bispectral index for assessing level of consciousness during propofol sedation and hypnosis. Anesth Analg 2000, 91(6):1398-403.

5. Iselin-Chaves IA, EI Moalem HE, Gan TJ: Changes in the auditory evoked potentials and the bispectral index following propofol or propofol and alfentanil. Anesthesiology 2000, 92(5):1300-10.

\section{Submit your next manuscript to BioMed Central} and take full advantage of:

- Convenient online submission

- Thorough peer review

- No space constraints or color figure charges

- Immediate publication on acceptance

- Inclusion in PubMed, CAS, Scopus and Google Scholar

- Research which is freely available for redistribution

Submit your manuscript at www.biomedcentral.com/submit
C Biomed Central 